\title{
Beriberi áratug eftir magahjáveituaðgerð - sjúkratilfelli
}

\author{
Linda Ó. Árnadóttir ${ }^{1}$ lknanemi, Svanur Sigurbjörnsson ${ }^{2}$ lknir, Tómas Guðbjartsson ${ }^{1,3}$ læknir
}

\section{Á G R I P}

Beriberi-sjúkdómur stafar af skorti á vítamíninu píamíni sem er langoftast afleiðing vannæringar en getur verið fylgikvilli skurðaðgerða. Rúmlega fertug kona sem gengist hafði undir magahjáveituaðgerð 10 árum áđur leitaði á bráđamóttöku Landspítala vegna máttleysis og dofa. Við skoðun voru lærvöðvar rýrir og sinaviðbrögð i neðri útlimum ógreinanleg. Einkenni bentu til fjöltaugakvilla sem talinn var samrýmast einkennum beriberi en magn píamíns í blóði mældist töluvert undir viðmiðunarmörkum. Hún var meðhöndluð með 300 mg af píamíni í æð og einkenni tóku að̃ hjað̃na. Píamínskort í pessu tilfelli má sennilega rekja að̃ mestu til magahjáveituaðgerðar og vannæringar tengda henni. Petta er sjaldgæfur fylgikvilli sem ber að hafa í huga hjá sjúklingum með fjöltaugakvilla, jafnvel löngu eftir slíka aðgerð.

\section{Inngangur}

Beriberi má rekja til píamínskorts og geta einkennin verið fjölbreytileg par sem máttleysi og dofi eru algengust. ${ }^{1}$ Píamín, einnig pekkt sem B1-vítamín, er vatnsleysanleg sameind sem er forveri margra mikilvægra virkra afleiða, par á meðal píamín pýrófosfats og píamín prífosfats. ${ }^{2}$ Píamín pýrófosfat er nauðsynlegt fyrir ýmis efnaskipti líkamans, svo sem í efnahvörfum Krebs-hringsins. ${ }^{3}$ Píamín prífosfat tekur pátt í myndun taugaboða í útlægum taugum en rekja má algengustu einkenni beriberi til truflunar á peim. ${ }^{2,3}$ Helmingunartími píamíns er einungis 10-20 dagar og mjög litlar birgðir eru geymdar af pví í líkamanum. ${ }^{2}$ Pví verður að neyta píamíns reglulega í fæðu til að koma í veg fyrir skort. Fæðan verður að vera fjölbreytt pví píamín er aðallega að finna í kornvörum en einnig í minna magni í grænmeti og kjötvörum. ${ }^{3}$ Beriberi er sjaldséður sjúkdómur hér á landi enda tengist hann aðallega vannæringu og einhæfu mataræði í fátækari löndum heimsins. Petta á sérstaklega við um landsvæði par sem hýðislaus hrísgrjón eru meginuppistaða fæðunnar, eins og í Suðaustur-Asíu. ${ }^{2}$ Á Vesturlöndum greinist sjúkdómurinn helst hjá sjúklingum sem pjást af vannæringu og langvinnri áfengissýki. ${ }^{1,4}$ Beriberi hefur einnig verið lýst eftir kviðarholsskurðaðgerðir. ${ }^{1}$ Hér er lýst tilfelli sem greindist á bráđamóttöku Landspítala en sjúklingurinn hafði 10 árum áður gengist undir magahjáveituaðgerð vegna offituvandamála.

\footnotetext{
'Læknadeild Háskóla Íslands, ${ }^{2}$ slysa- og bráđadeild, ${ }^{3}$ skurðsviði Landspítala. Fyrirspurnum svarar Tómas Guðbjartsson, tomasgud@landspitali.is Höfundar fengu sampykki ættingja sjúklings fyrir pessari umfjöllun og birtingu.

Höfundar hafa útfyllt eyðublað um hagsmunatengsl.

https://doi.org/10.17992/lbl.2016.11.107
}

Greinin barst 16. mars 2016, sampykkt til birtingar 16. september 2016.

\section{Tilfelli}

Rúmlega fertug kona leitaði í tvígang með 5 daga millibili á bráðamóttöku Landspítala vegna vaxandi dofa og máttleysis í útlimum. Einkennin voru mest áberandi í ganglimum og fannst henni „eins og að hún stæði á brauðfótum og ætti erfitt með að standa óstudd“. Sömuleiðis kvartaði hún um dofa í fingurgómum og tám. Dregið hafði úr matarlyst og hún hafði kastað upp daglega um nokkurra vikna skeið. Pví léttist hún um nokkur kílógrömm en ástæða uppkastanna var ópekkt. Hún hafði auk pess margra ára sögu um ofnotkun áfengis, pó ekki vikurnar fyrir innlögn, og hafði alltaf nærst vel par til pessi veikindi með uppköstum gerðu vart við sig.

Í heilsufarssögu kom fram að hún hafði verið greind með sykursýki af tegund 2, sóragigt og punglyndi og gengist undir gallblöðrutöku og svuntuaðgerð á kvið. Tíu árum áður hafði hún jafnframt gengist undir magahjáveituaðgerð vegna offituvandamála; gerð var Roux-en-Y tenging á ásgörn við maga og rúmmál magans minnkað í kringum $50 \mathrm{ml}$ (mynd 1). Gangurinn eftir aðgerðina var eðlilegur og án alvarlegra fylgikvilla. Léttist hún um 35 kíló, mestmegnis á fyrstu mánuðum. Líkamspyngdarstuðull hennar lækkaði úr 37 í $25 \mathrm{~kg} / \mathrm{m}^{2}$. Jafnframt lækkaði blóðsykur pað mikið að hún gat hætt að taka sykursýkislyf. Hins vegar purfti hún að taka járntöflur vegna járnskortsblóðleysis og fékk B12-vítamínsprautur á priggja mánaða fresti vegna lágra B12-gilda í blóði. Fjórum árum eftir aðgerð var hún í tvígang greind með góðkynja magasár á hálfs árs tímabili, nánar tiltekið á mótum tengingar milli maga og ásgarnar. Var hún í bæði skiptin meðhöndluð með sýrustillandi prótónpumpuhemlum og löguðust einkenni á nokkrum vikum. Ári síðar var hún lögð inn vegna bráðra kviðverkja og kom pá í ljós rof á maga vegna góðkynja ætisárs sem var á sama stað og fyrri ætisár. Var sárinu lokað með opinni skurðaðgerð og gerð ný samtenging frá maga og yfir á ásgarnarhluta Roux-en-Y tengingarinnar. Eftir aðgerðina var henni ráðlagt að taka um ótilgreindan tíma omeprazole töflur, $20 \mathrm{mg}$ einu sinni á dag.

Við komu á bráđamóttöku var hún vel áttuð og lífsmörk innan eðlilegra marka. Ekki sáust merki um hjartabilun eða bjúg á út- 


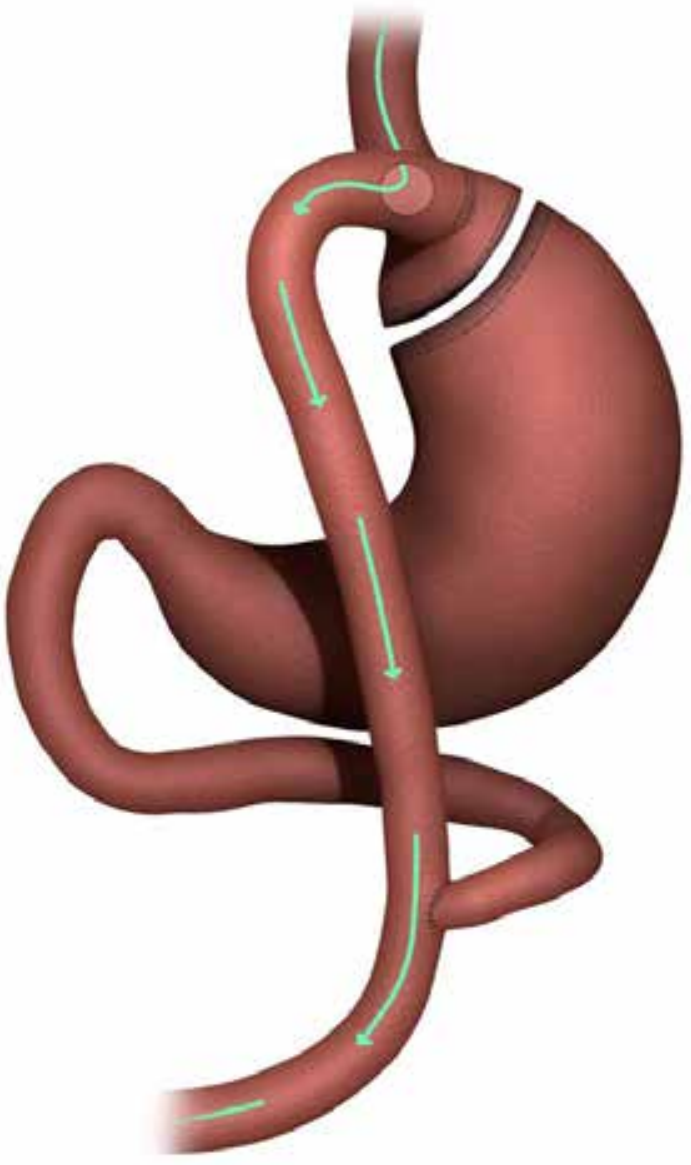

Mynd 1. Mynd af hjáveituaðgerðinni. Sá hluti magans sem tekur við fæðu er minnkaður í um pað bil $50 \mathrm{ml}$ og ásgörn síðan tengd með Roux-en-Y tengingu við magarestina. pannig er fæðunni beint fram hjá stórum hluta af smágirni. Mynd: Guðjón Örn Lárusson.

limum en hún var greinilega óstöðug við gang og vöðvar í neðri útlimum titruðu við áreynslu. Lærvöðvar voru áberandi rýrir. Við taugaskoðun fengust hvorki fram hné- né hælviðbrögð en á báðum upphandleggjum voru góð sinaviðbrögð í tvíhöfðavöðvum. Í fingurgómum og tám var skert snertiskyn og sjúklingurinn kvartaði um dofa í fingrum.

Á bráđamóttöku vaknaði fljótlega grunur um að einkennin, par með talinn fjöltaugakvillinn með vöðvarýrnun aðlægra (proximal) útlimavöðva, gætu samrýmst beriberi. Píamínskortur gæti hafa orðið vegna vannæringar eftir magahjáveituaðgerð og langvarandi uppkasta. Styrkur píamíns í blóði var mældur og barst svarið nokkrum dögum síðar par sem senda purfti sýnið erlendis til rannsóknar. Píamín í sermi mældist aðeins 71 nmól/L en viðmiðunargildi eru 100-300 nmól/L. Fékk hún pví greininguna beriberi án hjartabilunar og bjúgs, sem einnig er pekkt sem purrt beriberi (dry beriberi).

Á bráðamóttöku voru henni gefin 300 mg af píamíni í æð og dró úr sumum einkennanna næstu klukkustundirnar, sérstaklega ógleði, auk pess sem máttleysi minnkaði. Um kvöldið var hún útskrifuð heim til sín og lögð áhersla á að hún tæki daglega sterkt
B-vítamín sem bætiefni. Frekara eftirlit var fyrirhugað hjá heimilislækni par sem taka átti afstöðu til frekari píamíngjafar í æð. Gengu einkenni til baka að miklu leyti á næstu mánuðum pótt pau hyrfu ekki að fullu. Um hálfu ári síðar var hún lögð inn á Landspítala að nýju vegna lifrarbilunar sem rakin var til áfengismisnotkunar. Lést hún á gjörgæsludeild nokkrum vikum síðar.

\section{Umræða}

Hér er lýst tilfelli af purru beriberi sem tengist vannæringu eftir hjáveituaðgerð sem gerð var áratug áður. Algengustu einkenni vægs píamínskorts eru lystarleysi, hægðatregða, ógleði og uppköst, lækkað geðslag og preyta. Við alvarlegri skort fer að bera á einkennum frá úttaugum og vöðvum líkt og sáust í tilfellinu sem hér var lýst; einkenni sem eru dæmigerð fyrir fjöltaugakvilla í purru beriberi. Mest áberandi einkenni voru nánast upphafin sinaviðbrögð, veruleg vöðvarýrnun, minnkaður vöðvakraftur og skert snertiskyn auk dofa og verkja. Í beriberi er algengt að skyntruflanir og máttleysi byrji fjærst í tám og fingrum og færist síðan smá saman nær bol ${ }^{1,2}$ líkt og sást í pessu tilfelli.

Á Vesturlöndum er purrt beriberi ekki algengasta birtingarform píamínskorts heldur heilkenni Wernicke eða Korsakoff. Fjöltaugakvilli er pó oftast til staðar hjá peim sem greinast með Wernickeheilkenni og er stundum undanfari sjúkdómsins. ${ }^{4}$ Við langvarandi píamínskort verður hins vegar oftar hrörnun á úttaugum, líkt og sést í purru beriberi, eða hjartastækkun og hjartabilun eins og í blautu beriberi. Ofhleðsla glúkósa til viðbótar við píamínskort er hins vegar talin tengjast orsök taugasjúkdóma í heilakvilla Wernicke eða Korsakoff-heilkenni. ${ }^{4,5}$

Í okkar tilfelli er sennilegasta skýringin á píamínskorti magahjáveituaðgerð sem konan hafði gengist undir áratug áður, prátt fyrir að langvarandi uppköst og vannæring tengd ofnotkun áfengis gæti einnig hafa haft áhrif., ${ }^{4} 6$ Svipuðum tilfellum hefur verið lýst áður, meðal annars eftir magahjáveituaðgerð vegna offituvandamála hjá sjúklingi sem hafði einnig sögu um misnotkun áfengis. ${ }^{6}$ Pyngdartap eftir magahjáveituaðgerð skýrist af minni inntöku fæðu par sem sjúklingurinn verður fyrr saddur, en einnig vegna pess að frásog næringarefna í maga og mjógirni minnkar. ${ }^{78}$ Pannig getur dregið verulega úr upptöku píamíns og annarra næringarefna en einnig járns sem frásogast í smágirni, enda er tilgangur Roux-en-Y tengingarinnar að veita fæðunni fram hjá 100-150 cm af 500-600 cm heildarlengd smágirnis, og um leið allri skeifugörninni. ${ }^{7}$ Offituaðgerðir eru á meðal algengustu kviðarholsaðgerða víðast hvar á Vesturlöndum og tíðni peirra fer vaxandi á heimsvísu. ${ }^{9}$ Hér á landi hafa verið gerðar frá 23 til 82 hjáveituaðgerðir árlega síðustu fimm árin við offitu. Eru pá ekki taldar með offituaðgerðir par sem notast er við sultaról (gastric banding).

Magahjáveita er almennt talin örugg aðgerð og pótt tíðni fylgikvilla sé há er hægt að fyrirbyggja suma fylgikvilla, til dæmis með inntöku vítamína. ${ }^{10,11}$ Á meðal pessara fylgikvilla er píamínskortur en purru beriberi hefur áður verið lýst sem sjaldgæfum fylgikvilla eftir magahjáveituaðgerð., ${ }^{8,12,13}$ Einkenni eru pá svipuð og pegar píamínskortur hlýst af vannæringu. ${ }^{1}$ Algengast er að einkenni komi fram fyrstu mánuðina eftir aðgerðina pegar pyngdartap er hvað mest. ${ }^{13}$ Pó hefur verið lýst tilfelli par sem píamínskortur greindist 13 árum eftir magahjáveituaðgerð. ${ }^{6}$ Uppköst eru einnig 
pekktur fylgikvilli kviðarholsaðgerða, og pá sérstaklega magahjáveituaðgerða, pótt óvenjulegt teljist að pau sé langvinn. Pekkt er að langvarandi uppköst geta valdið píamínskorti og Wernicke-heilkenni ${ }^{8}$ en ógleði og uppköst eru jafnframt ein helstu einkenni beriberi. $^{2}$ Pannig getur verið erfitt að greina mun á pví hvort langvinn uppköst séu orsök og/eða afleiðing píamínskorts.

Helstu mismunagreiningar beriberi eru aðrir fjöltaugakvillar (polyneuropathy), einkum par sem einkenni byrja fjærst í útlimum, ná til bæði skyn- og afltauga og próast á löngum tíma. Í pessum hópi eru fjöltaugakvillar vegna langvinnrar sykursýki eða vannæring vegna skorts á öðrum B-vítamínum en píamíni, til dæmis B12. Einnig eru til arfgengir fjöltaugakvillar sem lýsa sér með svipuðum einkennum. ${ }^{14}$ Í okkar tilfelli hafði sjúklingurinn ekki haft sykursýki í næstum áratug og langtímablóðsykur var eðlilegur. Einnig voru mælingar á B12 innan eðlilegra marka. Hægt er að staðfesta greiningu beriberi með mælingu píamíns í blóði. Leiki vafi á greiningunni getur komið til greina að gera taugarafleiðnipróf og jafnvel taka taugasýni. ${ }^{14}$
Einkenni beriberi ganga yfirleitt til baka á nokkrum mánuðum eftir gjöf píamíns. Algengast er að gefa fyrst píamín í æð en síðan er notast við töflur ef frásog frá görn er eðlilegt. ${ }^{13}$ Í okkar tilfelli gengu sum einkennin að miklu leyti til baka á nokkrum klukkustundum. Frekari bati var hægur pótt henni tækist betur að nærast pegar uppköstin hættu.

Petta tilfelli sýnir hversu mikilvægt er að fylgjast vel með sjúklingum sem gengist hafa undir magahjáveituaðgerð og sjá til pess að peir taki til viðbótar fæðubótarefni sem frásogast í mjógirni. Einnig ber að hafa í huga aðra samverkandi pætti eins og misnotkun áfengis sem hafði sitt að segja í próun sjúkdómsins hjá sjúklingnum. Magahjáveituaðgerðir eru algengar aðgerðir og læknar purfa pví að kannast við helstu fylgikvilla en einnig pá sjaldgæfari eins og beriberi, sérstaklega pegar sjúklingar hafa einkenni fjöltaugakvilla eftir aðgerð.

Pakkir fá Björn Logi Pórarinsson taugalæknir og Páll Helgi Möller skurðlæknir fyrir aðstoð við upplýsingaöflun. Einnig fær Guðjón Örn Lárusson pakkir fyrir aðstoð við gerð myndefnis.

\section{Heimildir}

1. Koike $\mathrm{H}$, Iijima $\mathrm{M}$, Mori $\mathrm{K}$, Hattori $\mathrm{N}$, Ito $\mathrm{H}$, Hirayama $\mathrm{M}$, et al. Postgastrectomy polyneuropathy with thiamine deficiency is identical to beriberi neuropathy. Nutr 2004 20: 961-6.

2. Devlin TM. Textbook of Biochemistry: With Clinical Correlations, Sixth ed. Hoboken; Wiley-Liss, NJ 2006: 1102.

3. Wooley JA. Characteristics of Thiamin and Its Relevance to the Management of Heart Failure. Nutr Clin Pract 2008; 23: 487-93.

4. Pórarinsson BL, Ólafsson E, Kjartansson Ó, Blöndal H. Wernicke-sjúkdómur meðal áfengissjúkra. Læknablaðið 2011; 97: 21-8.

5. Carpenter KJ. Acute versus marginal deficiencies of nutrients. Nutr Rev 2002; 60: 277-80.
6. Grace DM, Alfieri MAH, Leung FY. Alcohol and poor compliance as factors in Wernicke's encephalopathy diagnosed 13 years after gastric bypass. Can J Surg 1998; 41: 389-92.

7. Elder KA, Wolfe BM. Bariatric Surgery: A Review of Procedures and Outcomes. Gastroenterol 2007; 132: 225371.

8. Angstadt J, Bodziner R. Peripheral Polyneuropathy from Thiamine Deficiency following Laparoscopic Roux-en-Y Gastric Bypass. Obes Surg 2005; 15:8 90-2.

9. Buchwald H, Oien DM. Metabolic/bariatric surgery worldwide 2011. Obes Surg 2013; 23: 427-36

10. Juhasz-Pocsine K, Rudnicki SA, Archer RL, Harik SI. Neurologic complications of gastric bypass surgery for morbid obesity. Neurol 2007; 68: 1843-50.
11. Podnos YD, Jimenez JC, Wilson SE, Stevens C, Nguyen NT. Complications after laparoscopic gastric bypass: A review of 3464 cases. Arch Surg 2003; 138: 957-61.

12. Gollobin C, Marcus W. Bariatric Beriberi. Obes Surg 2002; 12: 309-11.

13. Towbin $\mathrm{A}$, Inge $\mathrm{TH}$, Garcia VF, Roehrig $\mathrm{HR}$, Clements $\mathrm{RH}$, Harmon CM, et al. Beriberi after gastric bypass surgery in adolescence. J Pediatr 2004; 145: 263-7.

14. England JD, Asbury AK. Peripheral neuropathy. Lancet 2004; 363: 2151-61.

\section{ENGLISH SUMMARY}

\section{Beriberi 10 years after gastric bypass surgery - case report}

Linda Ó. Árnadóttir", Svanur Sigurbjörnsson², Tómas Guðbjartsson ${ }^{1,3}$

Beriberi is primarily related to malnutrition, but also known as a complication following abdominal surgical procedures. A 41 year old woman, who underwent gastric bypass surgery 10 years earlier, presented at the emergency department of Landspitali with general weakness and paresthesia. Physical examination revealed muscle atrophy and attenuated deep tendon reflexes in her lower limbs; presenting as polyneuropathy due to beriberi. The diagnosis was confirmed with serum thiamine levels measuring well below reference levels. She was treated with $300 \mathrm{mg}$ of thiamine intravenously and her condition started to improve. Thiamine deficiency in this case is most likely related to malnutrition secondary to the gastric bypass surgery. This rare complication must be considered in patients that present with polyneuropathy following bariatric surgery.

${ }^{1}$ Faculty of Medicine, University of Iceland, Emergency Medicine, ${ }^{2}$ Cardiothoracic Surgery, ${ }^{3}$ Landspitali University Hospital.

Key words: Beriberi, gastric bypass, thiamine, polyneuropathy, surgery, case report.

Correspondence: Tómas Guðbjartsson, tomasgud@landspitali.is 